\title{
Integration of Cloud Technologies in Teaching Foreign Languages in Higher Education Institutions
}

\author{
Iryna L. Pokrovska \\ Department of Turcology, Institute of Philology, \\ Taras Shevcenko National University of Kyiv \\ Kyiv, Ukraine \\ Tetiana M. Kolodko \\ Department of Teaching Methodology of Ukrainian and Foreign Languages and \\ Literatures, Institute of Philology, \\ Taras Shevchenko National University of Kyiv \\ Kyiv, Ukraine \\ Zamina K. Aliyeva \\ Department of Turkology, Institute of Philology, \\ Taras Shevchenko National University of Kyiv \\ Kyiv, Ukraine \\ Iryna V. Tymoshchuk \\ Department of foreign languages and intercultural communications, \\ Training Institute of the State Employment Service of Ukraine (Kyiv) \\ Kyiv, Ukraine

\section{Ruslan V. Vakariuk} \\ Department of Foreign Languages for Natural Sciences, \\ Faculty of Foreign Languages, Yuriy Fedkovych Chernivtsi National University \\ Chernivtsi, Ukraine
}

\begin{abstract}
This study was aimed at summarizing theoretical knowledge of students studying Economics, enhancing the educational process and training skills of independent long-term professional upgrade of students (sustainability training) through the use of an English-taught training program implemented through the use of MS Office 365 cloud services. The variational traits studied were identified: educational motivation, self-confidence, cognitive and creative skills. The study used methods that are recommended for quantitative research, namely: Rasch's models for measuring academic motivation, methods for determining the level of academic confidence; methods of diagnosis of cognitive reflection and decision making, and a questionnaire to
\end{abstract}


determine the level of creativity of thinking. The results of the diagnostic tests on academic motivation were processed using the Rasch Unidimensional Measurement Model (RUMM-2010) software, and the results of other tests were processed using SPSS 10.0.5., Statistica v. 5.5 A., MathCAD 2000 Pro. It has been found that the problem of integrating cloud technologies into the teaching foreign languages has been of interest of scholars, as the former are gradually becoming a fullfledged educational tool, allowing all institutions to create their own online spaces. In terms of language teaching methods, the used in this study teaching approach proved to create the learning environment helping to deal with the students' communication and interaction barriers, reluctance to being engaged resulted in the enhanced students' learning activity, their motivation for learning. This approach addressed the students' needs in developed logical (critical) thinking and creative tactic to problem-solving, student memory (cognitive component). The integration of cloud (education) services in general proved to increase the efficiency of the learning process.

Keywords: cloud technologies; foreign language teaching; higher education institutions; MS Office 365 services

\section{Introduction}

The integration of cloud technologies into the educational process as a whole, and in the foreign language teaching in particular, in higher education institutions allows not only modernizing the content of academic subjects, but also improving teaching methods, expanding the range of teaching techniques and enhancing learning activity of students (Genç İlter, 2015; Ahmadi, 2018). The topicality of studying the problem of integration of cloud technologies in the educational process is determined by a number of advantages, including but not limited to: cost-effectiveness - optimize the cost of software procurement and its systematic updating; flexibility and efficiency - customization of services for the needs of educational institutions, the possibility of unlimited data storage and automatic scaling of resources, minimum time consumption and financial costs for processing and analysis of data; environmental friendliness - electricity consumption is much lower than traditional computing; mobility - ongoing access to the information environment of higher education institutions (Lakshminarayanan, Kumar \& Raju, 2013; Goyal, 2017; Siddiqui et al., 2019).

\subsection{Literature review}

This study found that the key issues (seen as causes of failure) in teaching foreign languages had been insufficient learner engagement leading to lack of desire to study languages and discouraging students' experiences in their attempts to raise language fluency (Akbari et al., 2016; Jang, Kim \& Reeve, 2016), drilling-activities-based or reading-translation format (Bolitho \& West, 2017) of the classes that do not develop the students' cognitive and creative spheres. It implies that students' motivation and self-confidence in academic settings are related to language teaching methods. Furthermore, language teaching methods are mainly about employing pedagogic tools to create a relaxed learning environment to influence brain neuroplasticity that results in better cognitive 
and critical thinking activity obtained through increased learner motivation and self-confidence as long as their inner tensions are eliminated, the learning process gets contextualized and linked to the person's experience $(\mathrm{Li}$, Legault \& Litcofsky, 2014; Gözüyeşil \& Dikici, 2014).

\subsection{Use of technology in language teaching}

The use of technology is reported to have significantly changed foreign language teaching methods as technologies offer alternatives that make learning comprehensive, engaging and more productive in terms of student progress (Patel, 2013; Gilakjani, 2017) through a structured, person-to-person, manmachine and machine-machine interaction (İsman, 2012). The organization of educational activities of students when learning foreign languages based on cloud services allows bringing the educational process closer to the realities of the student's life and experience, gives access to both the student and the lecturer to authentic materials and authentic environment for communication and practice of all speech skills: reading, speaking, listening and writing that motivates the student to learn a foreign language (Kissling, 2012). The above goes in line with findings of $\mathrm{Wu}$, Marek and Yen (2012) and Alotebi (2016) reporting that if 'properly channelled' through Computer-Mediated Communication (CMC), learners show improved motivation, confidence, satisfaction, and greater actual academic performance. In addition, studies confirm that using the Internet also contributes to students' learning motivation.

The literature review identified a gap to address that is related to the influence of cloud-based approaches to teaching foreign languages on the motivation of academic achievements, academic self-confidence, cognitive and creative skills in tertiary students.

Therefore, the purpose of this study was to identify how an English-taught training program delivered through MS Office 365 cloud services (as a case of integration of cloud technology into the teaching foreign languages in higher education institutions) influences academic achievement motivation, academic self-confidence, cognitive and creative students' skills.

\section{Materials and methods}

This study was conducted in 2018 and aimed to summarize the theoretical knowledge of students studying Economics, to enhance the learning process and to train the skills of independent long-term professional upgrade of students (sustainability training) through the use of English- taught training program implemented through the MS Office 365 cloud services. The dependent variables to be investigated within this study framework were educational motivation, self-confidence, cognitive and creative skills. The study was conducted in three stages - empirical, experimental and ascertaining, and used the methods recommended for quantitative studies (Hancock, Stapleton \& Mueller, 2018; Bhatia, 2018). Diagnosis of educational motivation, self-confidence, cognitive and creative skills at the pre-experimental and post-experimental stage was performed using: Rasch's measurement model (Boone, 2016), Byrne, Flood and Griffin (2014) and Matotti (2011) academic confidence measurement techniques in modification of Sachitra and Bandara (2017); methods of diagnostics of 
cognitive reflection and decision making by Frederick (2005) and a questionnaire to determine the level of thinking creativity of Kumar, Kemmler and Holman (1997).

\subsection{Description of a training program}

The training program was English-taught and was based on the use of MS Office 365 cloud services - OneDrive, OneNote - for organizing and managing the project work of students studying Economics in their learning of professional English. Prime Decisions was additionally used to make informed decisions and MS Project - to plan the sequence of project implementation. The essence of the project was to develop a product of the future (based on our checklist) and packaging for it that would meet the concepts of triple sustainable development criteria (3P - People-Planet-Profit). With regard to the product, students had to take the following parameters into account: target audience, product benefit in solving a specific audience problem, environmental friendliness, profitability, and packaging, shape, size, colour, logo, relevant photo and text and competitive appearance, etc. To implement the project, students were divided into five cross-functional task forces, which were guided by a lecturer and consisted of students studying Marketing, Economics, Design, Consumption, Ecology, Psychology, etc. Typical forms of interaction between project team members were: online meetings for: brainstorming, analysis, presentation of information, negotiations, voting; correspondence, joint copywriting work, surveys of target audience through social networks (other Internet resources); creation of a promo-video and advertising campaign through the constituents of the "sales funnel" (website, YouTube channel, Instagram, etc.).

The evaluation of the projects in the voting format involved experts from among lecturers and business representatives, taking into account the number of likes to the promo-videos and social media pages. Let us visualize the course of the study (see Figure 1).

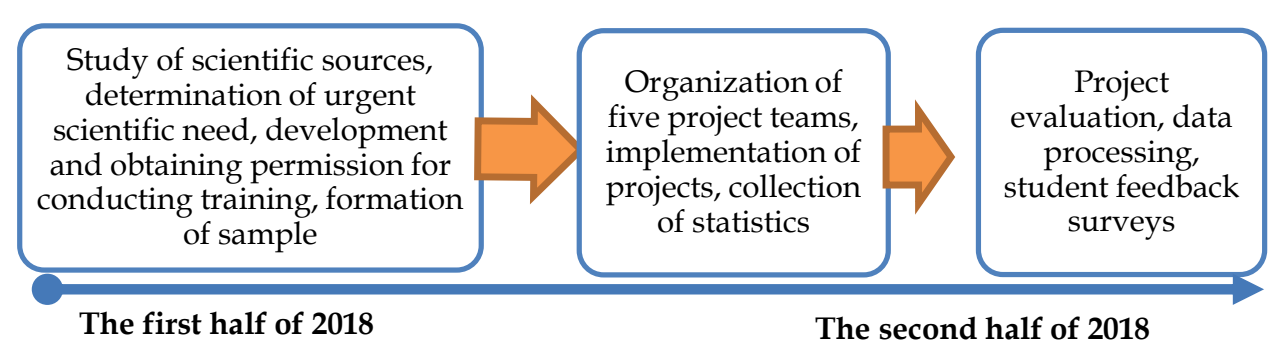

Figure 1: Course of the study

\subsection{Population Sampling}

This study relies on a random sampling technique. The general population for this study was 213 undergraduates in their $2^{\text {nd }}-3^{\text {rd }}$ year of the first (bachelor) level who were seeking a degree in Marketing and Advertising, International Economics, Finance, Green Economics and Ecology and Information Technology of the Vadym Hetman Kyiv National Economic University (KNEU) (133 persons) and the Kyiv National University of Trade and Economics (KNTEU) 
(101 persons) with the same level of success. After calculating the size of the required (representative) sample using the Qualtrics (n./d.) (with 90\% confidence probability, 9\% error) and applying exclusion criteria, such as: student's consent to participate, level of proficiency in English, a student's selfassessment in computer skills, the total population was reduced by 96 people, 60 people left. This figure was the starting point for the formation of the experimental group (EG) $(n=30)$ and the control group (CG) $(n=30)$. For the implementation of the projects, five cross-functional groups of six each were created in the EG.

At the pre-experimental stage, we found that the results of the diagnostic tests for educational motivation, self-confidence, cognitive and creative skills in both groups were approximately the same, suggesting that the groups could be involved in the study. The test results and comments are presented in Appendix section (see Tables A1-A5).

Based on the above results, a $t$-test was conducted with the above variables to examine whether there had been a significant difference between the means of two groups and whether the EG and CG sampled groups could be involved in the experiment (see Table 1 below).

Table 1: Prior-the-treatment T-test results showing the homogeneity of the EG and CG

\begin{tabular}{|c|c|c|c|c|c|c|c|}
\hline Axis & Groups & Mean & $S D$ & $S E$ & t-test & $d f$ & $p$ \\
\hline \multirow{2}{*}{ EM } & $\mathrm{EG}, n=30$ & 2.31 & 0.32 & \multirow{2}{*}{21} & \multirow{2}{*}{0.47} & \multirow{2}{*}{47} & \multirow{2}{*}{0.008} \\
\hline & $\mathrm{CG}, n=30$ & 2.56 & 0.28 & & & & \\
\hline \multirow{2}{*}{ SC } & $\mathrm{EG}, n=30$ & 2.63 & 0.36 & \multirow{2}{*}{22} & \multirow{2}{*}{0.51} & \multirow{2}{*}{47} & \multirow{2}{*}{0.027} \\
\hline & $C G, n=30$ & 2.67 & 0.41 & & & & \\
\hline \multirow{2}{*}{$\mathrm{CgS}$} & $\mathrm{EG}, n=30$ & 3.17 & 0.28 & \multirow{2}{*}{19} & \multirow{2}{*}{0.65} & \multirow{2}{*}{47} & \multirow{2}{*}{0.006} \\
\hline & $\mathrm{CG}, n=30$ & 3.13 & 0.29 & & & & \\
\hline \multirow{2}{*}{$\mathrm{CrS}$} & $\mathrm{EG}, n=30$ & 2.19 & 0.27 & \multirow{2}{*}{21} & \multirow{2}{*}{0.53} & \multirow{2}{*}{47} & \multirow{2}{*}{0.007} \\
\hline & $\mathrm{CG}, n=30$ & 2.23 & 0.31 & & & & \\
\hline \multirow{2}{*}{ DMS } & $\mathrm{EG}, n=30$ & 3.39 & 0.41 & \multirow{2}{*}{26} & \multirow{2}{*}{0.67} & \multirow{2}{*}{47} & \multirow{2}{*}{0.063} \\
\hline & $\mathrm{CG}, n=30$ & 3.41 & 0.43 & & & & \\
\hline
\end{tabular}

Note. EM - educational motivation; SC-self-confidence, CgS - cognitive skills, CrS - creative skills, DMS - decision-making skills; $p<.05 ; n$ - number of students; $M$ - arithmetic mean; $S D$ - standard deviations; $S E$ - standard error.

The above results suggested that both groups were approximately the same in composition and could participate in the experiment. 


\subsection{Tools for collecting and processing statistics}

The following tools were used to collect data in this study: Rasch academic motivation measurement models (Hancock, Stapleton \& Mueller, 2018), Byrne and Matotti academic confidence measurement techniques in modification of Sachitra and Bandara (2017); methods of diagnostics of cognitive reflection and decision making by Frederick (2005) and a questionnaire to determine the level of thinking creativity of Kumar, Kemmler and Holman (1997). The Rasch Unidimensional Measurement Model (RUMM-2010) software (Andrich, Sheridan \& Luo, 2000) was used to process the results of the diagnostic tests on educational motivation, and SPSS 10.0.5., Statistica v. 5.5 A., MathCAD 2000 Pro were used for the other tests.

\section{Results}

Five student-designed projects were the primary tangible and measurable result of this study. These included the ones entitled "Knowledge Pills for Lazy Students", "Laughing Gas for Rabbits", "Self-cleaning Plates", "Phonelickspittle" and "Potable Lie Detector".

The repeated measurements of the investigated variable which were educational motivation and self-confidence, along with cognitive, creative and decisionmaking skills showed the changes to have taken place in every variable in both groups. The results of the post-experimental diagnostics applying the above tools for collecting and processing statistics to the CG and EG students are provided in the Appendix section (see Tables A6-A10).

The $t$-test was conducted again to identify whether there was any shift in the mean figures of EG and CG sampled groups (see Table 2).

Table 2: Post-the-treatment T-test results to identify the shift in the mean figures of the variables for the EG and CG sampled groups

\begin{tabular}{|c|c|c|c|c|c|c|c|}
\hline Axis & Groups & Mean & $S D$ & $S E$ & t-test & $d f$ & $p$ \\
\hline \multirow{2}{*}{ EM } & $\mathrm{EG}, n=30$ & 2.92 & 0.41 & \multirow{2}{*}{19} & \multirow{2}{*}{0.43} & \multirow{2}{*}{47} & \multirow{2}{*}{0.088} \\
\hline & $C G, n=30$ & 2.63 & 0.31 & & & & \\
\hline \multirow{2}{*}{ SC } & $\mathrm{EG}, n=30$ & 3.12 & 0.39 & \multirow{2}{*}{21} & \multirow{2}{*}{0.56} & \multirow{2}{*}{47} & \multirow{2}{*}{0.032} \\
\hline & CG,$n=30$ & 2.93 & 0.37 & & & & \\
\hline \multirow{2}{*}{ CgS } & $\mathrm{EG}, n=30$ & 3.86 & 0.29 & \multirow{2}{*}{16} & \multirow{2}{*}{0.72} & \multirow{2}{*}{47} & \multirow{2}{*}{0.016} \\
\hline & $C G, n=30$ & 3.25 & 0.28 & & & & \\
\hline \multirow{2}{*}{$\mathrm{CrS}$} & $\mathrm{EG}, n=30$ & 3.02 & 0.31 & \multirow{2}{*}{17} & \multirow{2}{*}{0.58} & \multirow{2}{*}{47} & \multirow{2}{*}{0.071} \\
\hline & $C G, n=30$ & 2.69 & 0.27 & & & & \\
\hline \multirow{2}{*}{ DMS } & $\mathrm{EG}, n=30$ & 3.94 & 0.39 & \multirow{2}{*}{22} & \multirow{2}{*}{0.73} & \multirow{2}{*}{47} & \multirow{2}{*}{0.074} \\
\hline & $\mathrm{CG}, n=30$ & 3.55 & 0.42 & & & & \\
\hline
\end{tabular}

Note.EM - educational motivation; SC-self-confidence, $\mathrm{CgS}$ - cognitive skills, CrS - creative skills, DMS - decision-making skills; $p<.05 ; n$ - number of students; $M$ - arithmetic mean; $S D$ - standard deviations; $S E$ - standard error. 
It can be seen that there was a greater shift in the mean figures for all the variables for the EG than the ones for the CG that might be considered the result of the participation of the EG students in the project.

The consolidated results of diagnostic tests on educational motivation, selfconfidence, cognitive and creative skills at the pre-experimental and postexperimental stages can be seen in Figures 2, 3 below.

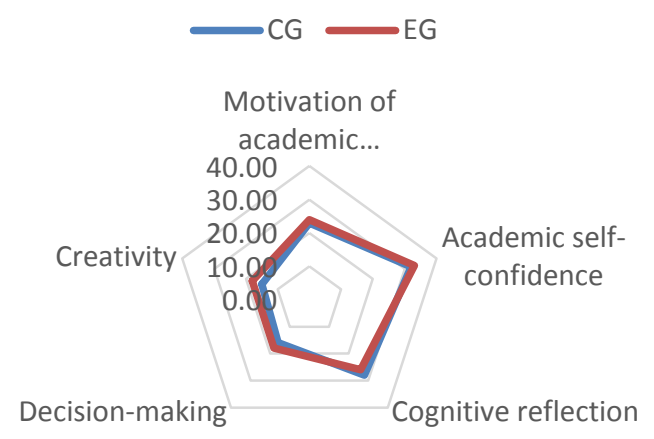

Figure 2: Consolidated results of diagnostic tests on educational motivation, selfconfidence, cognitive and creative skills at the pre-experimental stage, in $\%$

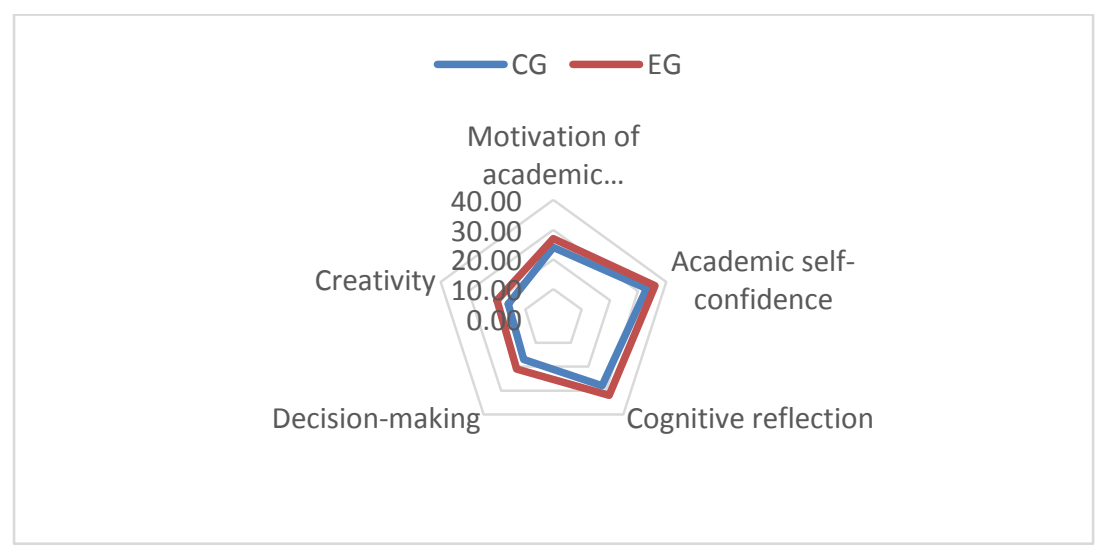

Figure 3: Consolidated results of diagnostic tests on educational motivation, selfconfidence, cognitive and creative skills at the post-experimental stage, in $\%$

As we can see from the tables and charts, both groups (CG and EG) showed positive changes (towards reduction) in overcoming students' attitude and behavioural difficulties, levels of academic self-confidence, cognitive reflection, decision-making, and creativity of thinking, however, these changes are more significant in the EG group, making up about $18 \%$. The results are illustrative of the effectiveness of the English-taught training program implemented through the use of MS Office 365 cloud services. 


\subsection{Limitations of the study}

The type of cloud services (MS Office 365), the student specialization, the age of the general population, the tools for collecting statistics can be considered as limitations of this study.

\section{Discussion}

The results of this study suggest that integration of cloud technologies into the process of teaching foreign languages at higher education institutions could be possible and effective, as evidenced by implemented English-taught training program based on the use of MS Office 365 cloud services.

The findings presented here are consistent with the ones from other national and international studies (Al-Zoube, El-Seoud \& Wyne, 2010; Altun, 2015; Barhate \& Narale, 2015; Khampusaen, 2014; Negoescu \& Boştină-Bratu, 2016; Patel, 2013; Siddiqui et al., 2019). The latter revealed the use of cloud-based teaching from the perspective of benefits like customising, cost-effectiveness, reaching the students, availability. Furthermore, some studies did not sufficiently present the content and the experimental process. This research followed it up and examined the benefits of the use of MS Office 365 cloud services from the perspective of a student.

This study found that the use of these services extended the pedagogical opportunities and increased the potential for influence on academic selfconfidence, cognitive reflection, speed of decision-making, creativity of thinking and helps to overcome students' attitude and behavioural difficulties by creating informal, creative and liberal environment. The students of EG had enhanced the desire for excellence and personal incentives, the desire to learn. They had gained more self-confidence in learning activities, had become more informed and prompter to make decisions. In the creative component of the personality of EG students there had been noticeable shifts in their behavioural self-regulation, the use of other people's help (team skills), the use of senses.

This study has complemented and deepened the study of the problem of cloud technology integration in higher education institutions in such areas as: integrating cloud technology into teaching and learning (Barhate \& Narale, 2015; Al-Zoube, El-Seoud \& Wyne, 2010); implementation of technologies in the process of teaching foreign languages (Altun, 2015; Negoescu \& Boştină-Bratu, 2016; Ahmadi, 2018) and the application of cloud technologies in teaching foreign languages (Khampusaen, 2014; Kravtsov \& Gnedkova, 2016). The theoretical and practical experience of the author of the publication outlined a niche for further research on the problem of integration of cloud technologies into the teaching process in higher education institutions.

\section{Conclusion}

It has been found that the problem of integrating cloud technologies into the teaching process in higher education institutions and into the teaching foreign languages, in particular, is a point of interest of academic scholars, as they gradually become a full-fledged educational tool, allowing all institutions to 
create their own online spaces. In terms of language teaching methods, the used in this study teaching approach proved to create the learning environment helping to deal with the students' communication and interaction barriers, reluctance to being engaged resulted in the enhanced students' learning activity, their motivation for learning.

This approach addressed the students' needs in developed logical (critical) thinking and creative tactic to problem-solving, student memory (cognitive component). Cloud services allowed visualizing complex content in a simple and convenient format (live scribing, interactive images (based on Thinglink and LearningApps.org) infographics, video presentations, etc.), which in turn engaged different channels of information perception: hearing and vision, as well as the imagination of a person, and contributes to its better understanding and memorization. The integration of cloud (education) services in general proved to increase the efficiency of the learning process.

The further research is needed in developing a model of professional training or advanced training of philologists in the use of cloud technologies in pedagogical activity.

\section{References}

Ahmadi, M. R. (2018). The Use of Technology in English Language Learning: A Literature Review. International Journal of Research in English Education, 3(2), 115125. doi:10.29252/ijree.3.2.115

Akbari, E., Naderi, A., Simons, P. R. J., \& Pilot, A. (2016). Student engagement and foreign language learning through online social networks. Asian-Pacific Journal of Second and Foreign Language Education, 1, 4. doi:10.1186/s40862-016-0006-7

Alotebi, H. (2016). Enhancing the Motivation of Foreign Language Learners Through Blended Learning. International Journal of Advanced Research in Education $\mathcal{E}$ Technology, 3(2), 51-55.

Altun, M. (2015). The integration of technology into foreign language teaching. International Journal on New Trends in Education and Their Implications, 6(1), 22-27.

Al-Zoube, M., El-Seoud, S. A., \& Wyne, M. F. (2010). Cloud Computing Based ELearning System. International Journal of Distance Education Technologies, 8(2), 5871. doi:10.4018/jdet.2010040105

Andrich, D., Sheridan, B., \& Luo, G. (1997-2012). RUMM2030: Rasch Unidimensional Models for Measurement. Perth, Australia: RUMM Laboratory.

Barhate, S. M., \& Narale, S. (2015). Cloud Based Teaching and Learning Environment for Smart Education. International Journal on Recent and Innovation Trends in Computing and Communication, 3(2), 38-41.

Bhatia, M. (2018). A Complete Guide to Quantitative Research Methods. Humans of Data. Retrieved from https://humansofdata.atlan.com/2018/06/quantitativeresearch-methods/

Bolitho, R., \& West, R. (2017). The internationalisation of Ukrainian universities: the English language dimension. Kyiv: Stal.

Boone, W. J. (2016). Rasch Analysis for Instrument Development: Why, When, and How? CBE life sciences education, 15(4). doi:10.1187/cbe.16-04-0148

Byrne, M., Flood, B., \& Griffin, J. (2014). Measuring the Academic Self-Efficacy of Firstyear Accounting Students. Accounting Education, 23(5), 407-423.

Frederick, S. (2005). Cognitive Reflection and Decision Making. Journal of Economic Perspectives, 19(4), 25-42. doi:10.1257/089533005775196732 
Genç İlter, B. (2015). How does technology affect language learning process at an early age? Procedia - Social and Behavioral Sciences, 199(2015), 311-316. doi:10.1016/j.sbspro.2015.07.552

Gilakjani, A. P. (2017). A review of the literature on the integration of technology into the learning and teaching of English language skills. International Journal of English Linguistics, 7(5), 95-106. doi:10.5539/ijel.v7n5p95

Goyal, A. (2017). 8 Benefits of Adopting Cloud-Based Applications in Education. eLearning Industry. Retrieved from https://elearningindustry.com/cloud-basedapplications-in-education-8-benefits

Gözüyeşil, E., \& Dikici, A. (2014). The Effect of Brain Based Learning on Academic Achievement: A Meta-analytical Study. Educational Sciences: Theory \& Practice, 14(2), 642-648. doi:10.12738/estp.2014.2.2103

Hancock, G. R., Stapleton, L. M., \& Mueller, R. O. (Eds.). (2018). The Reviewer's Guide to Quantitative Methods in the Social Sciences. New York: Routledge.

İşman, A. (2012). Technology and technique: An educational perspective. TOJET: The Turkish Online Journal of Educational Technology, 11(2), 207-213.

Jang, H., Kim, E.-J., \& Reeve, J. (2016). Why students become more engaged or more disengaged during the semester: A self-determination theory dual-process model. Learning and Instruction, 43, 27-38. doi:10.1016/j.learninstruc.2016.01.002

Khampusaen, D. (2014). Teaching English Language with Cloud-Based Tools. International Journal of the Computer, the Internet and Management, 22(1), 87-91.

Kissling, E. M. (2012). Techniques and Principles in Language Teaching, Third Edition (Book Review). Retrieved from https://pdfs.semanticscholar.org/b9fb/e8d83b069c57deec5aa1a8967f085fb7664 b.pdf

Kravtsov, H., \& Gnedkova, O. (2016). The Use of Cloud Services for Learning Foreign Language (English). Retrieved from http://ceur-ws.org/Vol-1614/paper_87.pdf

Kumar, V. K., Kemmler, D., \& Holman, R. E. (1997). The Creativity Styles Questionnaire-Revised. Creativity Research Journal, 10(1), 51-58. doi:10.1207/s15326934crj1001_6

Lakshminarayanan, R., Kumar, B., \& Raju, M. (2013). Cloud Computing Benefits for Educational Institutions. Retrieved from https://arxiv.org/ftp/arxiv/papers/1305/1305.2616.pdf

Li, P., Legault, J., \& Litcofsky, K. A. (2014). Neuroplasticity as a function of second language learning: anatomical changes in the human brain. Cortex, 58, 301-24. doi:10.1016/j.cortex.2014.05.001.

Matoti, S. N. (2011). Measuring the Academic Self-Efficacy of Students at a South African Higher Education Institution. Journal of Psychology in Africa, 21(1), 151-154.

Negoescu, A., \& Boştină-Bratu, S. (2016). Teaching and Learning Foreign Languages with ICT. Scientific Bulletin, 21(1), 21-27. doi:10.1515/bsaft-2016-0032.

Patel, C. (2013). Use of multimedia technology in teaching and learning communication skill: An analysis. International Journal of Advancements in Research \& Technology, 2(7), 116-123.

Qualtrics. (n./d.). Sample Size Calculator. Retrieved from https://www.qualtrics.com/blog/calculating-sample-size/

Sachitra, V., \& Bandara, U. (2017). Measuring the Academic Self-Efficacy of Undergraduates: The Role of Gender and Academic Year Experience. International Journal of Educational and Pedagogical Sciences, 11(11), 2443-2448.

Siddiqui, S. T., Alam, S., Khan, Z. A., \& Gupta, A. (2019). Cloud-Based E-Learning: Using Cloud Computing Pl`atform for an Effective E-Learning. In: S. Tiwari, M. C. Trivedi, K. K. Mishra, A. K. Misra, \& K. K. Kumar (Eds.), Smart Innovations in 
Communication and Computational Sciences. Proceedings of ICSICCS-2018 (pp. 335346). Singapore: Springer.

Wu, W.-C., Marek, M., \& Yen, L. L. (2012). Promotion of EFL Student Motivation, Confidence, and Satisfaction Via a Learning Spiral, Peer-Scaffolding, and CMC. International Journal of Computer-Assisted Language Learning and Teaching, 2(3), 5475. doi:10.4018/ijcallt.2012070104.

\section{Appendix A}

Table A1: Pre-experimental mean values form diagnostic tests on educational motivation (by Rasch Academic Motivation Measurement Model (Njiru, 2003)

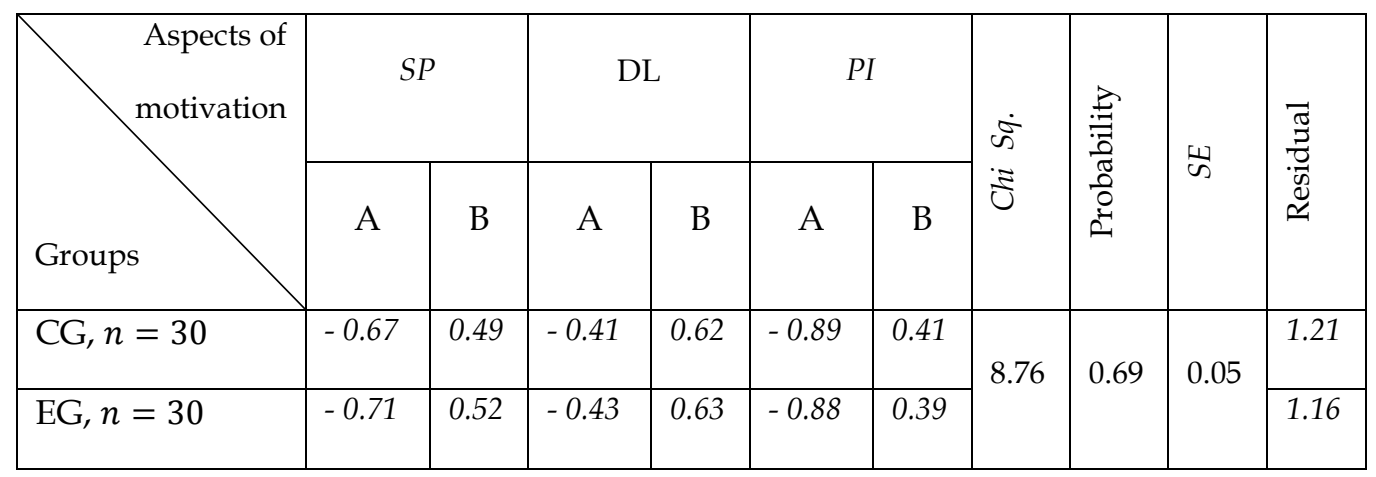

Note: SP - Striving for Perfection (standards, goals, objectives, efforts, values and capabilities); DL Desire to Learn (interest, learning from others and being responsible for their own learning); PI Personal Incentives (external, internal and social benefits); A - attitude difficulties, B - behavioral difficulties.

The residual figures being 1.21 for the CG and 1.16 for the EG, which are supposed to vary between $-2<x<+2$ suggest that they were acceptable. Even though the figures seemed to fit the Rasch's model, attitudinal aspects of personal incentives were inclined to be the lowest while behavioural features of desire to learn reached its high of 0.62 in the CG and 0.63 in the EG.

Table A2: Pre-experimental mean values from diagnostic tests to determine the level of academic self-confidence (by Byrne, Flood and Griffin (2014) and Matoti (2011) method in modification of Sachitra and Bandara (2017))

\begin{tabular}{|c|c|c|c|c|c|c|}
\hline Groups & $\begin{array}{c}\text { The mean value } \\
\text { of student } \\
\text { responses(a five- } \\
\text { point Likert scale) }\end{array}$ & $S D$ & $\begin{array}{c}\text { Cronbach's } \\
\text { alpha }\end{array}$ & \multicolumn{2}{|c|}{$p$-value } & \multicolumn{2}{|c|}{$\begin{array}{c}\text { Average level } \\
\text { of academic } \\
\text { confidence, } \%\end{array}$} \\
\cline { 1 - 6 } CG, $n=30$ & 3.24 & .946 & \multirow{2}{*}{$0.791(>0.7)$} & $<0.05$ & 64 & 36 \\
\cline { 1 - 2 } & 3.21 & .944 & & & 62 & 38 \\
\hline
\end{tabular}

It seemed clear the figures for the level of academic self-confidence mwasured with a five-point Likert scale were almost similar in both groups (CG - 3.24 and EG - 3.21). 
Table A3: Pre-experimental mean figures for the diagnosis of cognitive reflection (by the method of Frederick (2005))

\begin{tabular}{|c|c|c|c|c|c|}
\hline \multirow{2}{*}{ Groups } & \multirow{2}{*}{$\begin{array}{c}\text { The average indicator for the results } \\
\text { of the diagnosis of cognitive reflection }\end{array}$} & \multicolumn{2}{|c|}{ Low level } & \multicolumn{2}{|c|}{ High level } \\
\cline { 3 - 6 } & & 0 & 1 & 2 & 3 \\
\hline CG, $n=30$ & 1.51 & $25 \%$ & $25 \%$ & $25 \%$ & $25 \%$ \\
\hline EG, $n=30$ & 1.53 & $24 \%$ & $24 \%$ & $26 \%$ & $26 \%$ \\
\hline
\end{tabular}

Judging by the mean values for cognitive reflection, the mean values suggested that both groups performed approximately equally (CG - 1.51 and EG - 1.53).

Table A4: Mean figures from decision-making diagnostics (by the method of Frederick (2005))

\begin{tabular}{|l|c|c|c|c|c|}
\hline \multirow{2}{*}{ Decision type } & \multicolumn{2}{|c|}{$\begin{array}{c}\text { Low level of } \\
\text { cognitive reflection }\end{array}$} & \multicolumn{2}{c|}{$\begin{array}{c}\text { High level of } \\
\text { cognitive reflection }\end{array}$} & \multirow{2}{*}{$\begin{array}{c}\text { Statistical } \\
\text { significance }\end{array}$} \\
\cline { 2 - 5 } & CG & $E G$ & CG & EG & \\
\hline Impulsive & +1.01 & +1.02 & -0.21 & -0.23 & $\mathrm{p}<0.001$ \\
\hline Delayed & +1.05 & +1.07 & +1.06 & +1.08 & n.s. \\
\hline $\begin{array}{l}\text { Determined by the } \\
\text { foreseeable consequences }\end{array}$ & +2.49 & +2.47 & +1.64 & +1.59 & $\mathrm{p}<0.01$ \\
\hline Determined by hesitation & -1.16 & -1.15 & +0.11 & +0.13 & $\mathrm{p}<0.01$ \\
\hline
\end{tabular}

The mean figures distributed by the decision type, the one entitled "Determined by the foreseeable consequences" appeared dominant.

Table A5: Pre-experimental mean values from the diagnosis of the level of thinking creativity on eight scales (5-point rating scale) (by the methodology and questionnaire of Kumar, Kemmler and Holman (1997))

\begin{tabular}{|l|c|c|c|c|c|c|c|c|c|}
\hline \multicolumn{1}{r|r}{ Scales } & 1 & 2 & 3 & 4 & 5 & 6 & 7 & 8 & $\begin{array}{c}\text { Cronbach's alpha } \\
\text { (average) }\end{array}$ \\
\cline { 1 - 6 } CG $n=30$ & 3.4 & 3.7 & 2.9 & 3.1 & 2.6 & 2.1 & 3.1 & 2.3 & .76 \\
\hline EG, $n=30$ & 3.1 & 3.5 & 2.6 & 3.6 & 2.4 & 2.3 & 3.5 & 2.5 & \\
\hline
\end{tabular}

Conventions: Questionnaire scales: 1 - Kumar and Holman's global measure of creativity; 2- Belief in Unconscious Processes; 3 - Use of techniques; 4 - Use of other people; 5 - Final Product Orientation; 6 - Environmental control/ Behavioral self-regulation; 7 - Superstition; 8 - Use of Senses

It looks undoubtful that the figures for creativity parameters are more or less the same and more or less equally distributed on the scale. 
Table A6: Post-experimental mean results of diagnostic tests on educational motivation (by Rasch Academic Motivation Measurement Model (Njiru, 2003))

\begin{tabular}{|c|c|c|c|c|c|c|c|c|c|c|}
\hline \multirow{2}{*}{$\begin{array}{r}\text { Aspects of } \\
\text { motivation of } \\
\text { academic } \\
\text { achievements }\end{array}$} & \multicolumn{2}{|c|}{$S P$} & \multicolumn{2}{|c|}{ DL } & \multicolumn{2}{|c|}{ PI } & \multirow{2}{*}{$\begin{array}{l}\dot{\tilde{D}} \\
\overrightarrow{\tilde{U}}\end{array}$} & \multirow{2}{*}{ 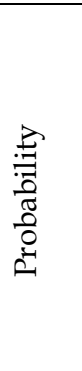 } & \multirow{2}{*}{ w } & \multirow{2}{*}{ 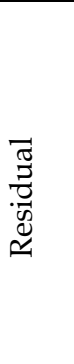 } \\
\hline & A & B & A & B & A & B & & & & \\
\hline $\mathrm{CG}, n=30$ & -0.65 & 0.47 & -0.39 & 0.60 & -0.86 & 0.39 & 776 & 065 & 005 & 1.19 \\
\hline $\mathrm{EG}, n=30$ & -0.65 & 0.46 & -0.39 & 0.57 & -0.83 & 0.34 & & & & 1.13 \\
\hline
\end{tabular}

Conventions: SP - Striving for Perfection (standards, goals, objectives, efforts, values and capabilities); DL - Desire to Learn (interest, learning from others and being responsible for their own learning); PI - Personal Incentives (external, internal and social benefits); A - attitude difficulties, B behavioral difficulties.

Table A7: Post-experimental mean results of diagnostic tests to determine the level of academic self-confidence (by Byrne, Flood and Griffin (2014) and Matoti (2011) method in modification of Sachitra and Bandara (2017))

\begin{tabular}{|c|c|c|c|c|c|c|}
\hline \multirow[t]{2}{*}{ Groups } & \multirow{2}{*}{$\begin{array}{l}\text { The average value } \\
\text { of student } \\
\text { responses(a five- } \\
\text { point Likert scale) }\end{array}$} & \multirow[t]{2}{*}{$S D$} & \multirow[t]{2}{*}{$\begin{array}{c}\text { Cronbach's } \\
\text { alpha }\end{array}$} & \multirow[t]{2}{*}{$p$-value } & \multicolumn{2}{|c|}{$\begin{array}{c}\text { Average level } \\
\text { of academic } \\
\text { confidence, } \%\end{array}$} \\
\hline & & & & & Yes & No \\
\hline $\mathrm{CG}, n=30$ & 3.28 & .945 & \multirow{2}{*}{$0,793(>0,7)$} & \multirow{2}{*}{$<0.05$} & 68 & 32 \\
\hline $\mathrm{EG}, n=30$ & 3.88 & .945 & & & 72 & 28 \\
\hline
\end{tabular}

Table A8: Post-experimental mean results of the diagnosis of cognitive reflection (by the method of Frederick (2005))

\begin{tabular}{|c|c|c|c|c|c|}
\hline \multirow{2}{*}{ Groups } & \multirow{2}{*}{$\begin{array}{c}\text { The average indicator for the results } \\
\text { of the diagnosis of cognitive reflection }\end{array}$} & \multicolumn{2}{|c|}{ Low level } & \multicolumn{2}{|c|}{ High level } \\
\cline { 3 - 6 } & & 0 & 1 & 2 & 3 \\
\hline CG, $n=30$ & 1.52 & $25 \%$ & $25 \%$ & $24 \%$ & $26 \%$ \\
\hline EG, $n=30$ & 1.58 & $20 \%$ & $24 \%$ & $28 \%$ & $28 \%$ \\
\hline
\end{tabular}


Table A9: Post-experimental mean results of decision-making diagnostics (by the method of Frederick (2005))

\begin{tabular}{|l|c|c|c|c|c|}
\hline \multirow{2}{*}{ Decision type } & \multicolumn{2}{|c|}{$\begin{array}{c}\text { Low level of } \\
\text { cognitive reflection }\end{array}$} & \multicolumn{2}{c|}{$\begin{array}{c}\text { High level of } \\
\text { cognitive reflection }\end{array}$} & \multirow{2}{*}{$\begin{array}{c}\text { Statistical } \\
\text { significance }\end{array}$} \\
\cline { 2 - 5 } & CG & EG & CG & EG & \\
\hline Impilsive & +1.00 & +0.79 & -0.20 & -0.20 & $\mathrm{p}<0.001$ \\
\hline Delayed & +1.03 & +0.98 & +1.02 & +1.26 & n.s. \\
\hline $\begin{array}{l}\text { Determined by the } \\
\text { foreseeable consequences }\end{array}$ & +2.51 & +2.68 & +1.65 & +1.73 & $\mathrm{p}<0.01$ \\
\hline Determined by hesitation & -1.02 & -0.94 & +0.12 & +0.18 & $\mathrm{p}<0.01$ \\
\hline
\end{tabular}

Table A10: Pre-experimental mean results of the diagnosis of the level of thinking creativity on eight scales (5-point rating scale), post-experimental stage (by the methodology and questionnaire of Kumar, Kemmler and Holman (1997))

\begin{tabular}{|l|c|c|c|c|c|c|c|c|c|}
\hline Scales & 1 & 2 & 3 & 4 & 5 & 6 & 7 & 8 & $\begin{array}{c}\text { Cronbach's alpha } \\
\text { (average) }\end{array}$ \\
\hline CG, $n=30$ & 3.5 & 3.9 & 3.1 & 3.2 & 2.8 & 2.2 & 3.3 & 2.5 & .79 \\
\hline EG, $n=30$ & 3.8 & 4.1 & 2.9 & 3.9 & 2.8 & 2.7 & 3.9 & 2.9 & \\
\hline
\end{tabular}

Conventions: Questionnaire scales: 1 - Kumar and Holman's global measure of creativity; 2- Belief in Unconscious Processes; 3 - Use of techniques; 4 - Use of other people; 5 - Final Product Orientation; 6 - Environmental control/ Behavioral self-regulation; 7 - Superstition; 8 - Use of Senses. 